Dep. of Food Hygiene,

Animal Health Research Institute.

\title{
THE EFFECT OF SOME TOXIC BIOGENIC AMINES ON THE QUALITY OF SOME MEAT PRODUCTS WITH A TRIAL TO REDUCE ITS LEVELS
}

(With 5 Tables and 4 Figures)

\author{
By \\ HANAA H.A. EL-MOSSALAMI; \\ EMAN I.K. EL-MOSSALAMI \\ and Y.A. ABDEL-HAKEIM \\ (Received at 11/9/2011)
}

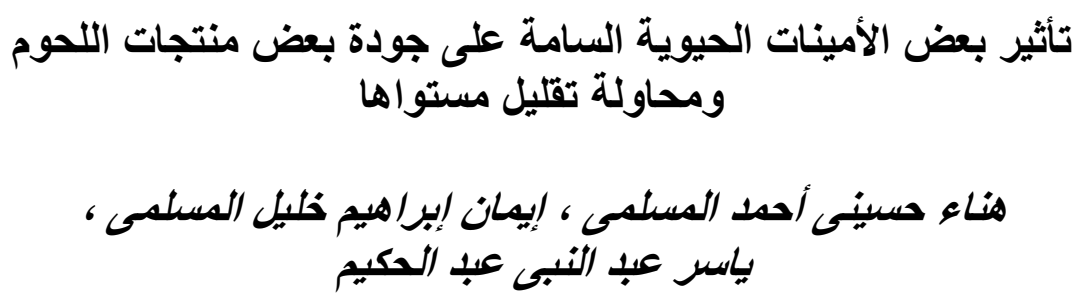

تم تجميع عشرون عينة من منتجات اللحوم ( • ( عينات من كل من السجق الجاف و اللانشون)

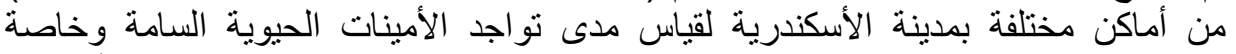

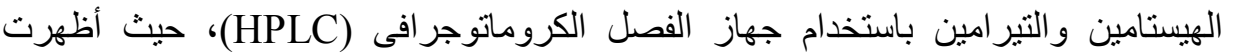

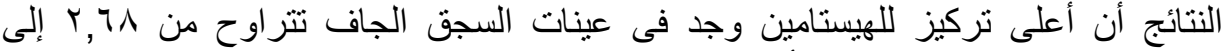

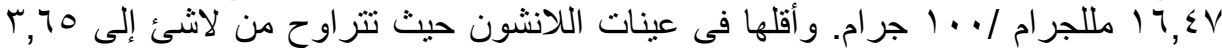

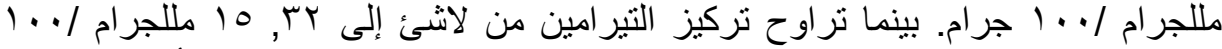

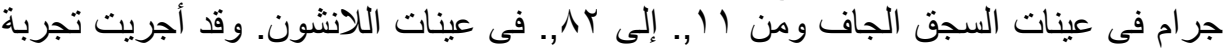

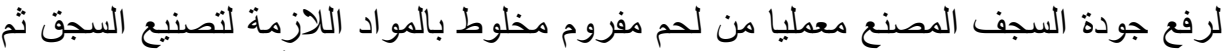

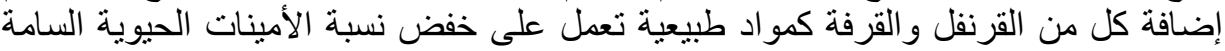

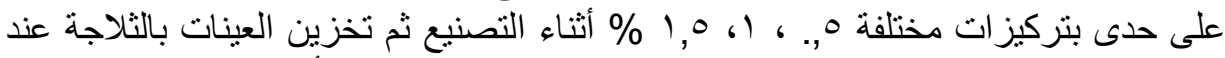

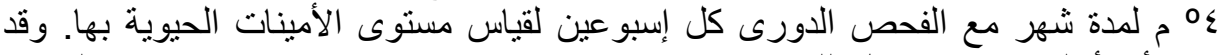

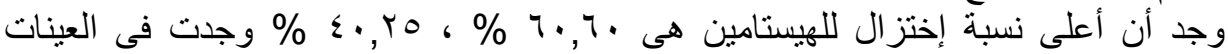

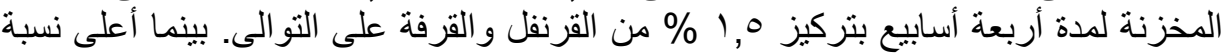

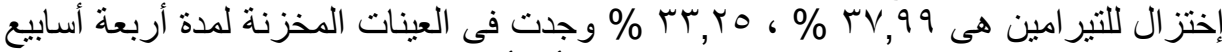

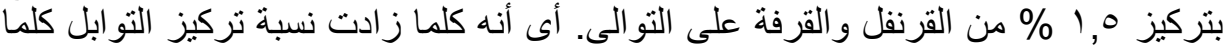
كان تأثير ها أكبر فى خفض كمية الأمينات الحيوية السامة فى المنتج. وقد تمت مناقتشة الأهمية 


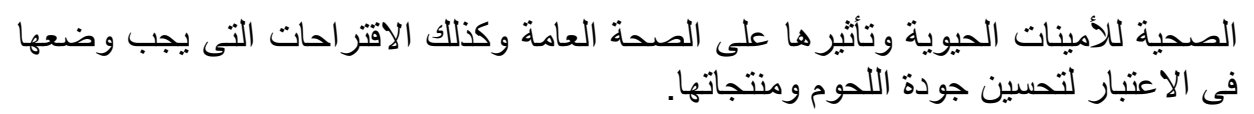

\section{SUMMARY}

Twenty samples of meat products (dry sausage and luncheon) ten samples of each were randomly collected from different localities of Alexandria city. Collected samples were subjected to biogenic amine examination. Histamine and tyramine were determined by HPLC. Histamine concentration was the higher in dry sausage (2.68 to 16.47 $\mathrm{mg} / 100 \mathrm{~g}$ ) than luncheon not detected (ND) to $3.65 \mathrm{mg} / 100 \mathrm{~g}$. Tyramine was ranging between ND to $15.32 \mathrm{mg} / 100 \mathrm{~g}$ in dry sausage and ranging between 0.11 to $0.82 \mathrm{mg} / 100 \mathrm{~g}$ in luncheon. For improvement the quality of sausage manufactured by fresh minced meat that purchased from butcher and mixed with the ingredients were used in sausage mixture, the addition of Clove or Cinnamon at levels of $0.5,1.0$ and $1.5 \%$ during manufactured of fresh sausage is used to reduce the production of histamine and tyramine. All samples stored under refrigeration condition at $4^{\circ} \mathrm{C}$ and were periodically withdraw for analysis of biogenic amines at Zero, 2 and 4weeks, respectively. The highest reduction percentage of histamine $(60.60 \%$ and $40.25 \%)$, were found in samples stored for 4 weeks with $1.5 \%$ clove and cinnamon, respectively. While the highest reduction percentage of tyramine $(37.99 \%$ and $33.25 \%)$, were found in samples stored for 4 weeks with $1.5 \%$ clove and cinnamon, respectively. The public health significance of the biogenic amines as well as the suggested measures for improving the quality of produced products has been discussed.

Key words: Biogenic amines, histamine, tyramine, meat products, sausage, luncheon.

\section{INTRODUCTION}

Biogenic amines are basic nitrogenous compounds with low molecular weight formed mainly by decarboxylation of amino acids or by amination and transamination of aldehydes and ketones (Halász et al., 1994; Silla-Santos, 1996; Zaman et al., 2009). This compounds are ubiquitous and play an important role in human and animal 
physiological function (Jansen et al., 2003; Suzzi and Gardini, 2003; Önal, 2007). Low level of biogenic amines in food is considered no significance health risk for consumption Bodmer et al., 1999.

Based on the mode of action, biogenic amines can be differentiated into vasoactive and psychoactive amines (Sellers et al., 2006). Psychoactive amines influence neural transmitters in the central neural system, while vasoactive amines act either directly or indirectly on the vascular system. Histamine, putrescine and cadaverine are psychoactive amines, while tyramine, tryptamine and phenylethylamine are vasoactive amines. Histamine exerts its toxic by interacting with receptors $\left(\mathrm{H}_{1}, \mathrm{H}_{2}\right.$ and $\left.\mathrm{H}_{3}\right)$ on cellular membranes which are found in the cardiovascular system and in various secretory glands (Shalaby, 1997; Sellers et al., 2006). Histamine causes dilatation of peripheral blood vessels, capillaries and arteries, resulting in hypotension, urticaria, flushing and headache. Histamine also induced contraction of intestinal smooth muscle, mediated by $\mathrm{H}_{1}$ receptor, causes abdominal cramp, diarrhea, nausea and vomiting. Moreover, stimulation of sensory and motor neuron by histamine causes pain and itching (Russell and Maretic, 1986; Lehane and Olley, 2000; Gonzaga et al., 2009). The action of vasoactive presser tyramine and phenylethylamine can cause hypertensive crisis in individuals on monoamine oxidase inhibitor (MAOI) drugs therapy. The physiological effects of tyramine include peripheral vasoconstriction, increase the cardiac output, increases respiration, elevated blood sugar, releases noradrenaline and causes migraine (Shalaby, 1997; Premont et al., 2001; Sellers et al., 2006). Putrescine and cadaverine can cause hypotension and potentiate toxicity of other amines, particularly histamine (Bjeldanes et al., 1978; Shalaby, 1997; Emborg et al., 2006).

The toxicological effect of biogenic amines can only occur when they are ingested in excessive amounts or when the natural mechanisms for their catabolism are inhibited or genetically deficient. Human intestinal tract normally detoxifies these compounds in food by enzyme monoamine oxidase (MAO) and diamine oxidase (DAO). Detoxification efficiency varies considerably among individual and was affected by several factors. Dietary intake of some MAO inhibitors is the main factor suppressed detoxification of biogenic amines (Brink et al., 1990; Til et al., 1997). Unfortunately, MAO inhibitors are still remaining an 
important class of drugs for a variety of psychiatric conditions, including depressive illnesses, anxiety and eating disorders (Walker et al., 1996; Kalac, 2009). It has also been reported that drugs used for antidepressants were nonselective irreversible of MAO, while drugs used for anti Parkinsonism were selective reversible inhibitior (Sellers et al., 2006). Therefore, those who are taking this kind if medicinal therapy should avoid consume food products with high potential concentration of biogenic amines. Putrescine and cadaverine hamper the detoxification of histamine and tyramine, tryptamine inhibit DAO and phenylethylamine inhibit HMT (histamine N-methyltransferase) (Eitenmiller et al., 1980; Stratton et al., 1991; Silla-Santos, 1996; Mohan et al., 2009).

Biogenic amines formation in food products is either a result of endogenous amino acids decarboxylase activity in raw food material or the growth of decarboxylase positive microorganisms under conditions favorable for enzyme activity. Therefore, prerequisites for biogenic amines formation in foods including the availability of free amino acids, the presence of decarboxylase active microorganism and environmental condition enabling microorganism growth and their enzymatic activity (Brink et al., 1990; Halász et al., 1994; Silla-Santos, 1996; Shalaby, 1997). Biogenic amines formation was also possibly altered by the presence of proteolytic enzymes as they play an important role in the release of free amino acids from protein tissues which offer the substrate for decarboxylation activity.

Meat and meat products have repetitively been reported to contain biogenic amines (Maihala et al., 1995; Eerola et al., 1997; Hernández-Jover et al., 1997; Kaniou et al., 2001; Bover-Cid et al., 2006; Galgano et al., 2009). The most prevalent biogenic amines in meat and meat products are tyramine, cadaverine, putrescine and also histamine (Ruiz-Capillas and Jiménez-Colmenero, 2004; Stadnik and Dolatowski, 2010).

Some amines such as tyramine, putrescine and cadaverine can be formed during storage of meat (Hernández-Jover et al., 1997; Galgano et al., 2009). As tyramine concentrations in stored beef was found the highest on the meat surface, that it can be reduced effectively by washing (Kaniou et al., 2001; Paulsen et al., 2006). 
Fermented meat products, constitute one of the foods in which considerable amounts of biogenic amines can be found as a consequence of the use poor quality raw materials, contamination and inappropriate conditions during processing and storage. Additionally, the microorganisms responsible for the fermentation process may contribute to biogenic amines accumulation (Bover-Cid et al., 2006; LatorreMoratalla et al., 2010). The nonprotein nitrogen fraction which increases during fermentation includes the presence of free amino acids, precursors of biogenic amines. The major protease activity is derived from endogenous meat enzymes. Proteolysis is favoured by the denaturation of proteins as a consequence of acidity increase, dehydration and action of sodium chloride (Eerola et al., 1997; Suzzi and Gardini, 2003).

Many authors (Maijala et al., 1995; Eerola et al., 1997; Komprda et al., 2004) observed significant differences in biogenic amines content in fermented meat products depending on raw material hygienic quality. However, the same material can lead to very different amine levels in final products depending on the presence of decarboxylating microorganisms, either derived from environmental contamination or from starter cultures and the conditions supporting their growth and activity. Amines content and profiles may vary depending on various extrinsic and intrinsic factors during the manufacturing process, such as $\mathrm{pH}$, redox potential, temperature, $\mathrm{NaCl}$, the size of the sausage, hygienic conditions of manufacturing practices and effect of starter cultures (Gardini et al., 2001; Komprda et al., 2004; Latorre-Moratalla et al., 2008).

Naturally occurring specific inhibitory substances in spices and additives cause inhibition of biogenic amines formation (Komprda et al., 2004). Substances are clove and cinnamon. They delay biogenic amine production in Myeolchi-jeot (Mah et al., 2009). The effect of spices have specific effects on bacteria that produce biogenic amines (Wendakoon and Sakaguchi, 1992). Ethanol extracts of allspice, cloves and cinnamon found to delay biogenic amine formation by Enterobacter aerogenes (Naila et al., 2010). The inhibitory effect was improved with the addition of sodium chloride (Gardini et al., 2001; Suzzi and Gardini, 2003). Cinnamic aldehyde, a component of cinnamon and eugenol a compound of cloves were found to be the most effective inhibitors of biogenic 
amine formation by specific bacteria, E. aerogenes (Zaika, 1988; Thoroski et al., 1989; Wendakoon and Sakaguchi, 1995).

This study was planned to fulfill the following points:

1- Quantitative determination for histamine and tyramine in Luncheon and dry sausage sold in Alexandria markets using high performance liquid chromatography (HPLC).

2- Investigate the effect of clove and cinnamon added during preparation of sausage on the level of histamine and tyramine content during storage.

\section{MATERIALS and METHODS}

Collection of samples: 10 samples (500g each) from each of luncheon and dry sausage were collected from different localities of Alexandria City. Fresh minced meat $(8 \mathrm{~kg})$ was purchased from the butcher and transported immediately in an ice box to the laboratory for manufactured of fresh sausage. Samples of meat products were prepared by mincing and $50 \mathrm{~g}$ was taken for extraction of biogenic amines.

Determination of biogenic amine content

Extraction of biogenic amines: biogenic amines were extracted by using the method previously described by (Lang et al., 2002; Ớnal, 2007). Ground samples (50g) were extracted with 5\% trichloroacetic acid (TCA) by $3 \times 75 \mathrm{ml}$ using a warring blender. Each blended mixture was centrifuged and the clear extracts were combined. The volume was adjusted to $250 \mathrm{ml}$ with trichloroacetic acid TCA (5\%) solution. The equivalent of $2 \mathrm{~g}$ of samples as the TCA extract $(10 \mathrm{ml}$ was made alkaline by adding $1 \mathrm{ml} 50 \%$ sodium hydroxide) and then extracted with $\mathrm{n}$-butanol/chloroform mixture $(1: 1 \mathrm{v} / \mathrm{v}) 3 \times 5 \mathrm{ml}$. The combined organic phase after addition of an equal amount of n-heptane (15) was extracted with several portions of $0.02 \mathrm{n} \mathrm{HCl}(1 \mathrm{ml}$ each) and the aqueous extract was dried by using current of air and water bath at $30^{\circ} \mathrm{C}$.

Derivative formation: (Paleologos et al., 2004)

The dansyle derivatives of the biogenic amines were formed by adding saturated sodium bicarbonate solution $(0.5 \mathrm{ml})$ to the residue (dry film), stopper and carefully mixed using vortex mixture, then carefully 
adding $1 \mathrm{ml}$ dansyle chloride solution (500 $\mathrm{mg}$ in $100 \mathrm{ml}$ acetone) and thoroughly mixed. After standing for more than 10 hours at room temperature, the dansyle-amines were extracted by adding $15 \mathrm{ml} \mathrm{HPLC}$ grade water and then the mixture was extracted with several portion (5ml each) of diethyl ether (HPLC grade). The combined ether extracts were evaporated to dryness by the aid of current of air and water bath at $35^{\circ} \mathrm{C}$. The residue was dissolved in $1 \mathrm{ml}$ acetonitrile.

\section{Preparation of standard solution:}

Histamine: Aliquot $41.40 \mathrm{mg}$ of histamine dihydrochloride (sigma chemical Co., N.7505) was dissolved in $50 \mathrm{ml}$ water HPLC grade (stock solution $0.5 \mathrm{mg} / \mathrm{ml}$ ).

Tyramine: Aliqout $31.39 \mathrm{mg}$ of tyramine (4-hydroxyphenylethylamine) hydrochloride (N, T. 2879) was dissolved in $50 \mathrm{ml}$ water HPLC grade. (stock solution $0.5 \mathrm{mg} / \mathrm{ml}$ ). $200 \mu$ of each stock standard solution was transferred to glass tube (using micropipette), then evaporated using current of air. The residue was subjected to dansylation as described above. The residue was dissolved in $5 \mathrm{ml}$ acetonitrile. $(1 \mathrm{ml}=20 \mu \mathrm{g}$ or $10 \mu \mathrm{l}=0.2 \mu \mathrm{g}$ each amine as derivative).

Detection: (Takagi and Shikata, 2004). Shimadzue HPLC was used for the quantitative estimation of biogenic amines. The conditions used as follow:

Mobile solvent: Solvent A: acetonitrile: $0.02 \mathrm{~N}$ acetic acid $(1: 9 \mathrm{v} / \mathrm{v})$. Solvent B: $0.02 \mathrm{~N}$ acetic acid: acetonitrile: methanole $(2: 9: 9 \mathrm{v} / \mathrm{v} / \mathrm{v})$. Program: gradient program $60 \%$ solvent B in solvent A to $100 \%$ solvent B using linear program over $30 \mathrm{~min}$ period and $1 \mathrm{ml}$ constant flow rate.

Detector: UV-Vis at $254 \mathrm{~nm}$.

Column: reversed phase C18 Shim Pack CLC. ODS. 0.15 m x 6.0.

Injection: $10 \mu \mathrm{l}$ of standard solution (as derivative) or sample was injected into HPLC apparatus.

Effect of addition of natural ingredients during preparation of sausage on the decrease of histamine and tyramine content during storage at $4^{\circ} \mathrm{C}$ :

The following ingredients were used in the sausage mixture according to Ali, 1985: Fresh minced meat (8kg containing 20\% fat), 3\% 
sodium chloride, $0.5 \%$ black pepper, $0.25 \%$ cubeb, $0.25 \%$ red pepper, $1 \%$ parsley, $0.25 \%$ ascorbic and $10 \%$ ice flakes. The solid spices were prepared using an electric mill. Minced meat was mixed with other ingredients except ice. Then the ice was added the mixture was minced and divided into seven batches. The first was left as control. Three batches were mixed with $0.5 \% .1 .0 \%$ and $1.5 \%$ cinnamon, respectively. The last three batches were mixed with $0,5 \%, 1.0 \%$ and $1.5 \%$ cloves, respectively. All batches were subjected to stuffing into cleaned natural mutton casing and stored under refrigeration condition at $4^{\circ} \mathrm{C}$ for one month. Samples were periodically withdrawn for analysis for biogenic amines at zero, 2 and 4 weeks, respectively.

Statistical analysis: The obtained data was analyzed statistically according to Perrie and Waston (1999).

\section{RESULTS}

The obtained data are recorded in Tables, 1, 2, 3 , 4, 5 \& Fig.,1.

Table 1: Histamine and tyramine content $(\mathrm{mg} / 100 \mathrm{~g})$ in some meat products.

\begin{tabular}{|c|c|c|c|c|}
\hline \multirow{2}{*}{$\begin{array}{c}\text { Type of meat } \\
\text { product }\end{array}$} & \multicolumn{2}{|c|}{ Histamine (mg/100g) } & \multicolumn{2}{c|}{ Tyramine (mg/100g) } \\
\cline { 2 - 5 } & Range & $\mathrm{M} \pm \mathrm{SD}$ & Range & $\mathrm{M} \pm \mathrm{SD}$ \\
\hline Dry sausage & $2.68-16.47$ & $9.93 \pm 5.01$ & $\mathrm{ND}-15.32$ & $5.15 \pm 6.49$ \\
& & & & \\
Luncheon & ND- 3.65 & $1.39 \pm 1.54$ & $0.11-0.82$ & $0.32 \pm 0.25$ \\
& & & & \\
\hline
\end{tabular}


Table 2: Influence of clove and cinnamon on histamine content $(\mathrm{mg} / 100 \mathrm{~g})$ in fresh sausage stored at $4^{\circ} \mathrm{C}$ for 4 weeks.

\begin{tabular}{|c|c|c|c|c|c|c|c|c|c|c|c|c|c|}
\hline \multirow{3}{*}{$\begin{array}{c}\text { Storage } \\
\text { Time / } \\
\text { Week }\end{array}$} & \multirow{3}{*}{ Control } & \multicolumn{6}{|c|}{ Cloves } & \multicolumn{6}{|c|}{ Cinnamon } \\
\hline & & \multicolumn{2}{|c|}{$0.5 \%$} & \multicolumn{2}{|c|}{$1.0 \%$} & \multicolumn{2}{|c|}{$1.5 \%$} & \multicolumn{2}{|c|}{$0.5 \%$} & \multicolumn{2}{|c|}{$1.0 \%$} & \multicolumn{2}{|c|}{$1.5 \%$} \\
\hline & & $\begin{array}{l}\mathrm{M} \pm \\
\mathrm{SD}\end{array}$ & $\begin{array}{l}\mathrm{R} \\
\% \\
\end{array}$ & $\begin{array}{l}\mathrm{M} \pm \\
\mathrm{SD}\end{array}$ & $\begin{array}{l}\mathrm{R} \\
\% \\
\end{array}$ & $\mathrm{M} \pm \mathrm{SD}$ & $\begin{array}{l}\mathrm{R} \\
\% \\
\end{array}$ & $\mathrm{M} \pm \mathrm{SD}$ & $\begin{array}{l}\mathrm{R} \\
\% \\
\end{array}$ & $\begin{array}{l}\mathrm{M} \pm \\
\mathrm{SD}\end{array}$ & $\begin{array}{l}\mathrm{R} \\
\% \\
\end{array}$ & $\begin{array}{l}\mathrm{M} \pm \\
\mathrm{SD}\end{array}$ & $\begin{array}{l}\mathrm{R} \\
\% \\
\end{array}$ \\
\hline 0 & $\begin{array}{c}1.44 \pm \\
0.05\end{array}$ & $\begin{array}{c}2.05 \pm \\
0.09\end{array}$ & - & $\begin{array}{c}1.40 \pm \\
0.09\end{array}$ & 2.78 & $\begin{array}{c}1.15 \pm \\
0.06\end{array}$ & 20.14 & $\begin{array}{c}1.31 \pm \\
0.11 \\
\end{array}$ & 9.03 & $\begin{array}{c}1.20 \pm \\
0.07\end{array}$ & 16.67 & $\begin{array}{c}1.33 \pm \\
0.01\end{array}$ & 7.64 \\
\hline 2 & $\begin{array}{c}18.47 \pm \\
0.30 \\
\end{array}$ & $\begin{array}{c}15.44 \pm \\
0.75 \\
\end{array}$ & 16.40 & $\begin{array}{c}11.39 \pm \\
0.39 \\
\end{array}$ & 38.33 & $\begin{array}{c}8.67 \pm \\
0.42\end{array}$ & 53.06 & $\begin{array}{c}18.42 \pm \\
1.32 \\
\end{array}$ & 0.27 & $\begin{array}{c}12.95 \pm \\
1.34 \\
\end{array}$ & 29.89 & $\begin{array}{c}11.89 \pm \\
0.30 \\
\end{array}$ & 35.63 \\
\hline 4 & $\begin{array}{c}28.20 \pm \\
1.00\end{array}$ & $\begin{array}{c}20.20 \pm \\
0.68\end{array}$ & 28.37 & $\begin{array}{c}15.57 \pm \\
0.06\end{array}$ & 44.79 & $\begin{array}{c}11.11 \pm \\
0.31\end{array}$ & 60.60 & $\begin{array}{c}27.06 \pm \\
2.18 \\
\end{array}$ & 4.04 & $\begin{array}{c}20.24 \pm \\
0.83\end{array}$ & 28.23 & $\begin{array}{c}16.85 \pm \\
0.11 \\
\end{array}$ & 40.25 \\
\hline Mean & $\begin{array}{c}16.04 \pm \\
11.74\end{array}$ & $\begin{array}{c}12.55 \pm \\
8.16\end{array}$ & 21.76 & $\begin{array}{c}9.45 \pm \\
6.31\end{array}$ & 41.08 & $\begin{array}{c}6.98 \pm \\
4.50\end{array}$ & 56.48 & $\begin{array}{c}15.60 \pm \\
11.42\end{array}$ & 2.74 & $\begin{array}{c}11.46 \pm \\
8.36\end{array}$ & 28.55 & $\begin{array}{c}10.02 \pm \\
6.86\end{array}$ & 37.53 \\
\hline
\end{tabular}

$\mathrm{M} \pm \mathrm{SD}=$ Mean of Triplicate Samples \pm Standard Deviation 
Table 3: Influence of clove and cinnamon on tyramine content $(\mathrm{mg} / 100 \mathrm{~g})$ in fresh sausage stored at $4^{\circ} \mathrm{C}$ for 4 weeks.

\begin{tabular}{|c|c|c|c|c|c|c|c|c|c|c|c|c|c|}
\hline \multirow{3}{*}{$\begin{array}{l}\text { Storage } \\
\text { Time / } \\
\text { Week }\end{array}$} & \multirow{3}{*}{ Control } & \multicolumn{6}{|c|}{ Cloves } & \multicolumn{6}{|c|}{ Cinnamon } \\
\hline & & \multicolumn{2}{|c|}{$0.5 \%$} & \multicolumn{2}{|c|}{$1.0 \%$} & \multicolumn{2}{|c|}{$1.5 \%$} & \multicolumn{2}{|c|}{$0.5 \%$} & \multicolumn{2}{|c|}{$1.0 \%$} & \multicolumn{2}{|c|}{$1.5 \%$} \\
\hline & & $\begin{array}{l}\mathrm{M} \pm \\
\mathrm{SD}\end{array}$ & $\begin{array}{l}\mathrm{R} \\
\%\end{array}$ & $\begin{array}{c}\mathrm{M} \pm \\
\mathrm{SD}\end{array}$ & $\begin{array}{l}\mathrm{R} \\
\%\end{array}$ & $\mathrm{M} \pm \mathrm{SD}$ & $\begin{array}{l}\mathrm{R} \\
\%\end{array}$ & $\mathrm{M} \pm \mathrm{SD}$ & $\begin{array}{l}\mathrm{R} \\
\%\end{array}$ & $\begin{array}{l}\mathrm{M} \pm \\
\mathrm{SD}\end{array}$ & $\begin{array}{l}\mathrm{R} \\
\%\end{array}$ & $\begin{array}{l}\mathrm{M} \pm \\
\mathrm{SD}\end{array}$ & $\begin{array}{l}\mathrm{R} \\
\%\end{array}$ \\
\hline 0 & $\begin{array}{c}0.65 \pm \\
0.07\end{array}$ & $\begin{array}{c}0.80 \pm \\
0.02\end{array}$ & - & $\begin{array}{c}0.58 \pm \\
0.08\end{array}$ & 10.77 & $\begin{array}{c}0.39 \pm \\
0.03\end{array}$ & 40.00 & $\begin{array}{c}0.61 \pm \\
0.02\end{array}$ & 6.15 & $\begin{array}{c}1.06 \pm \\
0.05\end{array}$ & - & $\begin{array}{c}0.52 \pm \\
0.05\end{array}$ & 20.00 \\
\hline 2 & $\begin{array}{c}12.22 \pm \\
0.33\end{array}$ & $\begin{array}{c}11.04 \pm \\
0.76\end{array}$ & 9.66 & $\begin{array}{c}6.70 \pm \\
0.29\end{array}$ & 45.17 & $\begin{array}{c}3.82 \pm \\
0.68\end{array}$ & 68.74 & $\begin{array}{c}9.62 \pm \\
0.92\end{array}$ & 21.28 & $\begin{array}{c}9.20 \pm \\
0.81\end{array}$ & 24.71 & $\begin{array}{c}7.09 \pm \\
0.49\end{array}$ & 41.98 \\
\hline 4 & $\begin{array}{c}16.90 \pm \\
1.47\end{array}$ & $\begin{array}{c}13.29 \pm \\
0.64\end{array}$ & 21.36 & $\begin{array}{c}10.48 \pm \\
0.06\end{array}$ & 37.99 & $\begin{array}{c}4.26 \pm \\
0.03\end{array}$ & 74.79 & $\begin{array}{c}15.02 \pm \\
0.96\end{array}$ & 11.12 & $\begin{array}{c}14.31 \pm \\
0.49\end{array}$ & 15.33 & $\begin{array}{c}11.28 \pm \\
0.81\end{array}$ & 33.25 \\
\hline Mean & $\begin{array}{c}9.92 \pm \\
7.28\end{array}$ & $\begin{array}{c}8.38 \pm \\
5.79\end{array}$ & 15.52 & $\begin{array}{c}5.92 \pm \\
4.33\end{array}$ & 40.32 & $\begin{array}{c}2.82 \pm \\
1.86\end{array}$ & 71.57 & $\begin{array}{c}8.42 \pm \\
6.33\end{array}$ & 15.12 & $\begin{array}{c}8.19 \pm \\
5.81\end{array}$ & 17.44 & $\begin{array}{c}6.30 \pm \\
4.72\end{array}$ & 36.49 \\
\hline
\end{tabular}

$\mathrm{M} \pm \mathrm{SD}=$ Mean of Triplicate Samples \pm Standard Deviation 
Table 4: Pair wise comparison of histamine content in sausage samples as a function of clove and cinnamon levels.

\begin{tabular}{|c|c|c|c|c|}
\hline \multicolumn{2}{|c|}{ Additives } & \multirow{2}{*}{$\begin{array}{c}\text { Mean } \\
\text { Difference } \\
(\mathrm{I})\end{array}$} & $\begin{array}{c}\text { Standard } \\
\text { Error }\end{array}$ & Signification \\
& & $(\mathrm{I}-\mathrm{J})$ & & \\
\cline { 1 - 2 } Control & $0.5 \%$ Cloves & $3.4704^{*}$ & 0.343 & 0.0000 \\
& $1.0 \%$ Cloves & $6.5833^{*}$ & 0.343 & 0.0000 \\
& $1.5 \%$ Cloves & $9.0589^{*}$ & 0.343 & 0.0000 \\
& 0.5 Cinnamon & 0.4389 & 0.343 & 0.9850 \\
& $1.0 \%$ Cinnamon & $4.5744 *$ & 0.343 & 0.0000 \\
& $1.5 \%$ Cinnamon & $6.0144 *$ & 0.343 & 0.0000 \\
\hline
\end{tabular}

The mean difference is significant at 0.05 level

Table 5: Pair wise Comparison of Tyramine content in sausage samples as a function of Clove and Cinnamon levels.

\begin{tabular}{|c|c|c|c|c|}
\hline \multirow{2}{*}{$(\mathrm{I})$} & $(\mathrm{J})$ & \multirow{2}{*}{$\begin{array}{c}\text { Mean } \\
\text { Difference } \\
(\mathrm{I}-\mathrm{J})\end{array}$} & $\begin{array}{c}\text { Standard } \\
\text { Error }\end{array}$ & Signification \\
\hline \multirow{2}{*}{ Control } & $0.5 \%$ Cloves & $1.5444^{*}$ & 0.280 & 0.0000 \\
& $1.0 \%$ Cloves & $4.0044^{*}$ & 0.280 & 0.0000 \\
& $1.5 \%$ Cloves & $7.1011^{*}$ & 0.280 & 0.0000 \\
& 0.5 Cinnamon & $1.5056^{*}$ & 0.280 & 0.0000 \\
& $1.0 \%$ Cinnamon & $1.7333^{*}$ & 0.280 & 0.0000 \\
& $1.5 \%$ Cinnamon & $3.6244^{*}$ & 0.280 & 0.0000 \\
\hline
\end{tabular}

The mean difference is significant at 0.05 level 

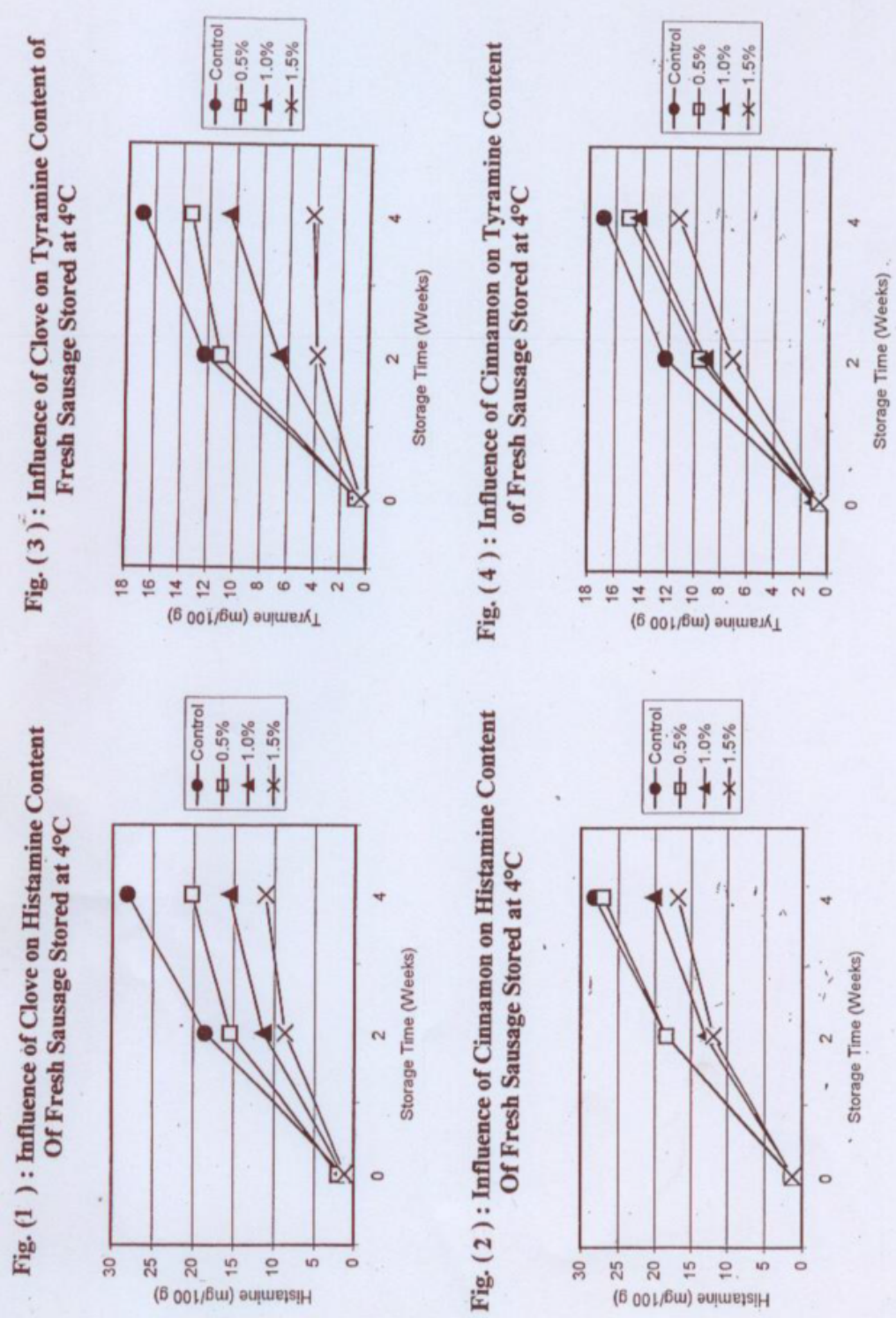


\section{DISCUSSION}

\section{Histamine and tyramine content $(\mathrm{mg} / \mathrm{100g})$ in some meat products Histamine content:}

From data in Table 1 histamine concentration is higher in dry sausage than that in luncheon. With respect to tyramine a relatively high level is detected in dry sausage samples. However, in the other investigated samples, tyramine is very low. From the data of Table 1 also dry sausage contained the highest level of histamine and tyramine among the investigated meat products. This may be related to the long fermentation period by the action of natural micro-flora of such product (Naila et al., 2010). During sausage ripening, histamine concentration increased Ten fold during the first three days of ripening, while the concentration of histidine was correspondingly decreased (Eerola et al., 1997).

The detected histamine level in dry sausage ranged from 2.68 to $16.47 \mathrm{mg} / 100 \mathrm{~g}$ (Table 1$)$ which is higher than the level of $(0.75$ to 10.50 $\mathrm{mg} / 100 \mathrm{~g}$ ), which was reported by Ali (1985) but lower than the level of 7.5 to $40.5 \mathrm{mg} / 100 \mathrm{~g}$ in dry sausage stated by Shalaby (1995). The detected histamine level in luncheon ranged from ND to $3.65 \mathrm{mg} / 100 \mathrm{~g}$, which is lower than the level of ( 9 to $23.4 \mathrm{mg} / 100 \mathrm{~g}$ ), which reported by Ali (1985).

\section{Tyramine content:}

Tyramine level detected in dry sausage is in the range of ND to $15.32 \mathrm{mg} / 100 \mathrm{~g}$, which is higher compared with the level of 2.55 to $7.00 \mathrm{mg} / 100 \mathrm{~g}$, which was reported by Ali (1985) but lower than the level of 9.5 to $52.8 \mathrm{mg} / 100 \mathrm{~g}$ in dry sausage determined by Shalaby and Rahman (1995). The detected tyramine level in luncheon ranged between 0.11 to 0.82 , which is lower than the level of ND to 7.65 $\mathrm{mg} / 100 \mathrm{~g}$ that reported by Ali (1985).

The variation noticed in the level of biogenic amines may be related to the variation in ripening process, quality of raw materials Maihala et al., 1995 and the natural of micro flora responsible for fermentation that may be variable and differ on their decarboxylase activity leading to variations in the production of biogenic amines (Suzzi 
and Gardini, 2003). Moreover, the concentration of nitrite and nitrate or other preservatives may be also responsible (Shalaby, 1997).

As for tyramine, none of the investigated samples reached to level $6 \mathrm{mg}$, which was reported to be a dangerous dose for patients receiving MAOIs (Yongmei et al., 2009). In sausage a level of $100 \mathrm{mg}$ histamine $/ 100 \mathrm{~g}$ sausage is considered the maximum level necessary to induce a toxic response in human (Gardini et al., 2009; Stadnik; Dolatowski, 2010).

\section{Influence of clove and cinnamon on histamine content of fresh sausage during storage at $4^{\circ} \mathrm{C}$.}

The results in Table 2 and Figs $1 \& 2$ revealed that expanding the storage time gradually increased histamine content in control samples was $1.44 \pm 0.05 \mathrm{mg} / 100 \mathrm{~g}$ increased gradually to $18.47 \pm 0.3 \mathrm{mg} / 100 \mathrm{~g}$ after 2 weeks and to $28.20 \pm 1.00 \mathrm{mg} / 100 \mathrm{~g}$ after 4 weeks. Addition of clove at various concentrations $(0.5,1.0$ and $1.5 \%)$ resulted in a dose dependent reduction of histamine level reaching $20.20 \pm 0.68,15.57 \pm$ 0.06 and $11.11 \pm 0.31 \mathrm{mg} / 100 \mathrm{~g}$, respectively at the end of storage period. The highest reduction percentage of histamine $(60.60 \%)$ was found in samples stored for 4 weeks with $1.5 \%$ cloves. Cinnamon also has a dose dependent reduction effect on the level of histamine. The highest effect obtained at $1.5 \%$ cinnamon the histamine content of the sausage was reduced by $40.25 \%$ after 4 weeks. The same effect of clove and cinnamon was detected by (Shakila et al., 1996) who pointed out that Indian mackerel treated with clove and cinnamon at 3\% and stored for up 24 hours at $30^{\circ} \mathrm{C}$ showed a significant inhibitory action of histamine, putrescine and tyramine. It was also reported that cloves and cinnamon were found to be the most affective spices against bacterial growth and biogenic amine formation than other studied (sage, black pepper, allspice, cumin, chill and nutmeg) (Wendakoon and Sakaguchi, 1992).

It may notice from the results that all the sausage samples contained histamine below $100 \mathrm{mg} / 100 \mathrm{~g}$. The limit that has been suggested to be the minimum level necessary to induce toxic response in humans. As well as the maximum mean level of detected histamine was $28.20 \mathrm{mg} / 100 \mathrm{~g}$, so consumption of $335 \mathrm{~g}$ of this sample could reach the toxic limit $(100 \mathrm{mg} / 100 \mathrm{~g})$. 


\section{Influence of clove and cinnamon on tyramine content of fresh sausage during storage at $4^{\circ} \mathrm{C}$.}

Results in Table 3 and Figs $3 \& 4$ showed that the tyramine content in control samples was $0.65 \pm 0.07 \mathrm{mg} / 100 \mathrm{~g}$ increased gradually during storage reaching $16.9 \pm 1.47 \mathrm{mg} / 100 \mathrm{~g}$ after 4 weeks. While in samples contained cloves at the investigated levels $(0.5,1.0$ and $1.5 \%)$, there was a significant reduction in the tyramine content due to addition of cloves in a dose dependent manner. The highest level of cloves $(1.5 \%)$ reduced the level of tyramine formed $74.79 \%$ after 4 weeks of storage. The same sequence was observed due to addition of cinnamon. Since the concentration of tyramine was reduced by $11.12 \%, 15.33 \%$ and $33.25 \%$ after 4 weeks of storage at the three studied levels $0.5,1.0$ and 1.5\%, respectively.

Concerning tyramine, the three studied levels of both spices showed a significant effect on the reduction of tyramine during storage period. Most samples contained tyramine level higher than the hazard limit $6 \mathrm{mg}$ with exception of sausage samples containing $1.5 \%$ cloves. It could be concluded that, although clove and cinnamon resulted in a significant reduction effect on histamine and tyramine in sausage samples, however tyramine still above the hazard level $(6 \mathrm{mg})$. There was no significant effect of cinnamon at $0.5 \%$ level on the concentration of histamine, while there was highly significant effect of cinnamon at 1.0 and $1.5 \%$ levels and cloves at the three studied levels on the reduction of histamine. It could be observed from the data of Tables 2 and 3 that the degree of effectiveness of clove was higher than of cinnamon on the reduction of both amines.

Results in Table 4 revealed that there is no significant effect of cinnamon at $0.5 \%$ level on the concentration of histamine, while there is highly significant effect of cinnamon at 1.0 and $1.5 \%$ levels and cloves at the three studied levels on the reduction of histamine. Concerning tyramine, the studied levels of both spices showed a significant effect on the reduction of tyramine during storage period (Table 5).

The results in Tables 4 and 5 showed that significant reduction in both histamine and tyramine levels due to addition of clove or cinnamon in fresh sausage stored at $4^{\circ} \mathrm{C}$ for 4 weeks. This could be attributed to the highly inhibitory effect of such spices to bacterial growth (Zaika, 1988). 
The major antimicrobial compound in clove and cinnamon are known to be eugenol and cinnamic aldehyde that inhibit the extra-cellular enzymes of bacteria (Thoroski et al., 1989) and may have an inhibitory action on the synthesis of decarboxylases, which might be a probable for the inhibition of amine production (Wendakoon and Sakaguchi, 1992).

\section{Control}

The existing method for controlling biogenic amines in food is refrigeration. However, since some bacteria that form biogenic amines can grow below $5^{\circ} \mathrm{C}$, refrigeration alone is not always controlling biogenic amines and thus emerging control measures need to be considered (Niala et al., 2010). Emerging control measures for delaying biogenic amine formation include high hydrostatic pressure (HHP), irradiation, packaging, microbial modeling and the use of food additives or preservatives. These methods only delay biogenic amines formation in food primarily through the inhibition of bacteria or the decarboxylase enzyme activity responsible for amine production. Application of sufficient heat or freezing storage can prevent further development of biogenic amines, although product needs to be protected from recontamination in the case of heat and from thawing in case of freezing (Stadnik and Dolatowski, 2010).

\section{In Conclusion:}

The choice of starter culture is fundamental to guarantee the quality of final products in relation to their biogenic amines content. For this reason, the inability to form biogenic amines, to survive during ripening and storage and to possess amine oxidase activity should be relevant criteria to be taken into consideration in the selection of starter cultures for the fermentation of dry sausages (Suzzi and Gardini, 2003; Karovičová and Kohajdová, 2005). The selection of lactic acid bacteria with application in meat fermentation has to take in consideration the various, specific requirements of the fermentation process (Roig-Sagués and Eerola, 1997). The importance of using measures focused on the hygienic quality of both raw material and processing units to avoid the development of aminogenic contaminant bacteria and in turn, to reduce biogenic amines content, is well known. However, proper hygiene may not be enough to avoid some biogenic amines formation and other technological measures must be applied (Latorre-Moratalla et al., 2010). 


\section{REFERENCES}

Ali, A.M. (1985): Amines in Egyptian foods (sausage, basterma, luncheon. Fiseek, moloha, frozen fish) in Egypt. Thesis Ph. D. in Food Sci. Faculty of Agriculture, Zagazig University.

Bjeldanes, L.F.; Schutz, D.E. and Morris, M.M. (1978): On the a etiology of scromboid poisoning: Cadaverine potentiation histamine toxicity in the guinea big. Food Cosmet. Toxicol., 16: 157-159.

Bodmer, S.; Imark, C. and Kneubühl, M. (1999): Biogenic amines in foods: Histamine and food processing. Inflamm. Res. 48: 296-300.

Bover-Cid, S.; Miguelez-Arrizado, M.J.; Latorre-Moratalla, L.L. and Vidal-Catou, M.C. (2006): Freezing of meat raw materioals affects tyramine and diamine accumulation in spontaneously fermented sausages. Meat Sci. 72: 62-68.

Brink, B.T.; Damink, C.; Joosten, H.M.L.J. and Huis, J.H.J.In't Velt, (1990): Occurrence and formation of biologically active amine in food. Int. J. Food Microbiol., 11: 73-84.

Eerola, S.; Roig-Sagués, A.X.; Lilleberg, L. and Aalto, H. (1997): Biogenic amines in dry sausages during shelf-life storage. Z. Lebensm. Unters. Forsch. A, 205: 351-355.

Eitenmiller, R.; Orr, J. and Wallis, W. (1980): Histamine formation in fish: Microbiological and Biochemical conditions. In: Chemistry and Biochemistry of Marine Food Products, Martin, R. (Ed). AVI, Connecticut, pp: 39-50.

Emborg, J.; Dalgaard, P. and Ahrens, P. (2006): Morganella psychrotolerans sp. Nov., a histamine producing bacterium isolated from various sea foods. Int. J. Syst. Evol. Microbiol., 56: 2473-2479.

Galgano, F.; Favati, F.; Bonadio, M.; Lorusso, V. and Romano, P. (2009): Role of biogenic amines as index of frehness in beef meat packed with different biopolymeric materials. Food Res. Int., 42: 1147-1152.

Gardini, F.; Martuscelli, M.; Caruso, M.C.; Galgano, F.; Crudele, M.A.; Favati, F.; Guezoni, M.E. and Suzzi, G. (2001): Effect of $\mathrm{pH}$, temperature and $\mathrm{NaCl}$ concentration on the growth kinetic, 
proteolytic activity and biogenic amines production of Enterococcus faecalis. Int. J. Food Microbiol., 64: 105-117.

Gonzaga, V.E.; Lescano, A.G.; Huamán, A.A.; Salmn-Mulanovich, G. and Blazes, D.L. (2009): Histamine levels in fish from markets in Lima, Peru. J. Food Prot., 72: 1112-1115.

Halasz, A.; Barath, A.; Sarkadi, L.S. and Holzapfel, W. (1994): Biogenic amines and their production by microorganisms in food. Trends Food Sci. Technol., 5: 42-49.

Hernández-Jover, T.; Izquierdo-Pulido, M.; Veciana-Nogués, M.T.; Mariné-Font, A. and Vidal-Carou, M.C. (1997): Biogenic amines and polyamine contents in meat and meat products. J. Agric. Food Chem., 45: 2098-2102.

Jansen, S.C.; Van Dusseldrop, M.; Bottema, K.C. and Dubois, A.E.J. (2003): Intolerance to dietary biogenic amines: a review. Ann. Allerg. Asthma Im., 91: 233-241.

Kalac, $P$. (2009): Recent advances in the research on biological roles of dietary polyamines in man. J. Appl. Biomed 7(2): 65-74.

Kaniou, I.; Samouris, G.; Mouratidou, T.; Eleftheriadou, A. and Zantopoulos, N. (2001): Determination of biogenic amines in fresh unpacked and vacuum-packed beef during storage at $4^{\circ} \mathrm{C}$. Food Chem., 74: 515-519.

Karovičová, J. and Kohajdová, Z. (2005): Biogenic amines in food. Chem. Pap. 59(1): 70-79.

Komprda, T.; Smělá, D.; Pechová, P.; Kalhotka, L.; Štencl, J. and Klejdus, B. (2004): Effect of starter culture, spice mix and storage time and temperature on biogenic amine content of dry fermented sausages. Meat Sci. 67: 607-616.

Lang, J.; Kathleen, T. and Christine, W. (2002): Comparison of a capillary electrophoresis method with high-performance liquid chromatography for the determination of biogenic amines in various food samples. J. Chroma. B., 779: 299-239.

Latorre-Moratalla, M.L. ; Veciana-Nogués, T. ; Bover-Cid, S.; Garriga, M. ; Aymerich, T.; Zanardi, E.; Ianieri, A.; Fraqueza, M.J.; Patarata, L.; Dorsinos, E.H.; Lauková, A.; Talon, R. and Vidal-Carou, M.C. (2008): Biogenic amines in traditional fermented sausages produced in selected European countries. Food Chem., 107: 912-921. 
Latorre-Moratalla, M.L.; Bover-Cid, S.; Talon, R. Garriga, M.; Zanardi, E.; Ianieri, A.; Fraqueza, M.J.; Elias, M.; Drosinos, E.H. and Vidal-Carou, M.C. (2010): Strategies to reduce biogenic amine accumulation in traditional sausage manufacturing. LWT-Food Sci. Technol., 43: 20-25.

Lehane, L. and Olley, J. (2000): Histamine fish poisoning revisited. Int. J. Food Microbiol., 58: 1-37.

Mah, J.H.; Kim, Y.J. and Hwang, H.J. (2009): Inhibitory effects of garlic and other spices on biogenic amine production in Myeolchi-Jeot, Korean salted and fermented anchovy product. Food Control, 20(5): 449-454.

Maijala, R.; Nurmi, E. and Fischer, A. (1995): Infleunce of processing temperature on the formation of biogenic amines in dry sausages. Meat Sci., 39: 9-22.

Mohan, C.O.; Ravishankar, C.N.; Gopal, T.K.S.; Kumar, K.A. and Lalitha, K.V. (2009): Biogenic amines formation in seer fish (Scomberomorus commerson) steaks pached with $\mathrm{O}_{2}$ scavenger during chilled storage. Food Res. Int., 42(3): 411-416.

Naila, A.; Flint, S.; Fletcher, G.; Bremer, P. and Meerdink, G. (2010): Control of biogenic amines in foods - Existing and Emerging Approaches. J. Food Sc., 75(7): 139-150.

Önal, A. (2007): A review: Current analytical methods for the determination of biogenic amines in foods. Food Chem., 103: $1475-1486$.

Paleologos, E.K.; Sarvaidis, I.N. and Kontominas, M.G. (2004): Biogenic amines formation and its relation to microbiological and sensory attributes in ice- stored whole, gutted and filleted Mediterranean sea bass (Dicentrarchus labrax). Food Microbiol., 21: 549-557.

Paulsen, P.; Hagen, U. and Bauer, F. (2006): Changes in biogenic amine contents, non-protein nitrogen and crude protein during curing and thermal processing of $M$. longissimus, pars lumborum of pork. Eur. Food Res. Technol., 223: 603-608.

Perrie, A. and Watson, L. (1999): Statistics in Veterinary and Animal's Science $1^{\text {st }}$ Ed. The bark well Science. Rd, UK.

Premont, R.T.; Gainetdinov, R.R. and Caron, M.G. (2001): Following the trace of elusive amines. Proc. Natl. Acad. Sci. USA., 98: 9474-9475. 
Roig-Sagués, A. and Eerola, S. (1997): Biogenic amines in meat inoculated with Lactobacillus sake starter strains and an aminepositive lactic acid bacterium. Z. Lebensm. Unters. Forsch. A, 205: 227-231.

Ruiz-Capillas, C. and Jiménez-Colmenero, F. (2004): Biogenic amines in meat and meat products. Crit. Rev. Food Sci. Nutr., 44(7-8): 489-499.

Russell, F.E. and Maretic, Z. (1986): Scombroid poisoning mini-review with case histories. Toxicon, 24(10): 967-973.

Sellers, B.J.M.; Staggs, C.G. and Bogle, M.L. (2006): Tyramine in foods and monoamine oxidase inhibitor drugs: A crossroad where medicine, nutrition, pharmacy and food industry coverage. J. Food Comp. Anal., 19: 556-565.

Shakila, G.; Vasandhara, R. and Vijoya-Rao, D. (1996): Inhibitory effect of spices on In-vitro histamine production and histidine decarboxylate activity of Morganella morganii and on bacterial amine formation in mackerel stored at $30^{\circ} \mathrm{C}$. Zeitsch. Lebensm. Untersch. Forsch., 203(1): 71-76.

Shalaby, A.R. and Rahman, H.A.A.E. (1995): Effect of potassium sorbate on development of biogenic amines during sausage fermentation. Food/Nahrung, 39(4): 308-315.

Shalaby, A.R.,(1997): Significance of biogenic amines to food safety and human health. Food Res. Int., 29(7): 675-690.

Silla-Santos, M.H. (1996): Biogenic amines: Their importance in foods. Int. J. Food Microbiol., 29: 213-231.

Stadnik, J. and Dolatowski, Z.J. (2010): Biogenic amines in meat and fermented meat products. Acta Sci. Pol., Technol. Aliment., 9(3): 251-263.

Stratton, J.E.; Hutkins, R.W. and Tylor, S.L. (1991): Biogenic amines in cheese and other fermented foods: a review. J. Food Protect., 54: 460-470.

Suzzi, G. and Gardini, F. (2003): Biogenic amines in dry fermented sausages: a review. Int. J. Food Microbiol., 88: 41-54.

Takagi, K. and Shikata, S.,(2004): Folw injection determination of histamine with a histamine dehydrogenase-based electrode. Analy. Chem. Acta., 505: 189-193. 
Thoroski, J.; Blank, G. and Biliardes, C. (1989): Eugenol induced inhibition of extra-cellular enzyme production by Bacillus subtilis. J. Food Prot., 2: 399-403.

Til, H.P.; Falke, H.E.; Prinsen, M.K. and Willems, M.I. (1997): Acute and subacute toxicity of tyramine, spermidine, spermine, putrescine and cadaverine in rats. Food Chem. Toxicol., 35 (3-4): 337-348.

Walker, S.E.; Shulman, K.I.; Taylor, S.A. and Gardner, D. (1996): Tyramine content of previously restricted foods in monoamine oxidase inhibitor diets. J. Clin. Psychopharmacol., 16: 383-388.

Wendakoon, C.N. and Sakaguchi, M. (1992): Effects of spices on growth and biogenic amine formation by bacteria in fish muscle. Amsterdam: Elsevier Science Publishers.

Wendakoon, C.N. and Sakaguchi, M. (1995): Inhibition of amino acid decarboxylase activity of Enterobacter aerogenes by active components in spices. J. Food Prot., 58: 280-283.

Yongmei, L.; Xiaohong, C. Mei, J.; Rahman, N.; Mingsheng, D. and Yan, G. (2009): Biogenic amines in Chinese soy sauce. Food Control, 20(6): 593-597.

Zaika, L.L. (1988): Spices and herbs: Their antimicrobial activity and its determination. J. Food Safety., 9: 97-118.

Zaman, M.Z.; Abdulamir, A.S.; Abu Bakar, F.; Selamat, J. and Bakar, J. (2009): A review: Microbiological, physicochemical and health impact of high level of biogenic amines in fish sauce. American J. App. Sci., 6(6): 1199-1211. 